\title{
MAPPING THE FOURFOLD GOSPEL: \\ TEXTUAL GEOGRAPHY IN THE EUSEBIAN APPARATUS*
}

\section{JEREMIAH COOGAN}

Eusebius of Caesarea (ca. 260-339 C.E.) invented a paratextual apparatus for reading Matthew, Mark, Luke, and John as a fourfold unity. Yet despite Eusebius's creativity and the long afterlife of his invention, the apparatus remains under-appreciated and widely misunderstood. This article argues that Michel de Certeau's distinction between itineraries and maps illuminates the innovative function of the Eusebian apparatus, which contrasts with earlier attempts at gospel harmony and synopsis. Instead of disrupting the narrative integrity of the four canonical gospels, Eusebius's map creates a canonical space that preserves gospel narrative and facilitates exegetical and liturgical appropriation.

\section{INTRODUCTION}

The iconic map of the London Tube is a marvel of practical cartography. The revolutionary design, invented by Harry Beck in 1933, has now been imitated by numerous urban transit systems around the world. The Tube map depicts only essential information: the sequence of stops on a given line, intersections with other lines, and whether a station is north or south of the River Thames. The regular spacing of stops on the map does not indicate actual distance along a line. Stops on different lines that look quite far apart can be almost next to each other on the ground - or vice versa. As a result, the Tube map is almost useless at street level. The map is for using the Tube, not navigating London as a whole. ${ }^{1}$ 
The gospel apparatus created by Eusebius of Caesarea (ca. 260-339 C.E.) offers a similarly schematic map for reading the fourfold canonical gospel. ${ }^{2}$ In this study, I apply Michel de Certeau's concept of textual geography to illuminate the purpose and function of Eusebius's apparatus. The geographical metaphor facilitates our understanding of a paratextual system that may appear arcane and overly complicated to modern readers. I argue further that this geographical reading draws attention to a significant feature of Eusebius's gospel apparatus that may otherwise go unnoticed. Eusebius creates a distinctive canonical space which preserves the narrative integrity (“itinerary" in de Certeau's terms) of the four canonical gospels. Eusebius's map of the gospels resists collapsing or effacing their narrative itineraries, while also largely resisting the "totalizing" and "regularizing" function which de Certeau ascribes to maps. I conclude this study by observing how Eusebius's innovative paratextual apparatus is able to insinuate new itineraries in the textual space of the fourfold gospel.

Within two centuries of its invention, Eusebius's apparatus was ubiquitous; one could hardly encounter the fourfold gospel without finding Eusebius's map in its margins. ${ }^{3}$ Yet in modern scholarship Eusebius's creation has suffered benign neglect. ${ }^{4}$ Except for art historians interested in the lavishly decorated canon tables of medieval manuscripts, the twentieth century offers just a handful of cases in which the Eusebian apparatus receives consideration in its own right. ${ }^{5}$ Only in the past few years has a small burst of activity centered on the Eusebian apparatus, reflecting a recent surge of interest in various paratextual features and in Eusebius himself. ${ }^{6}$ Even so, there has been little discussion of how the Eusebian apparatus functions, either as paratextual object or as exegesis. ${ }^{7}$ In the present study, I build on recent scholarship in order to explore how the Eusebian apparatus functioned within the landscape of Late Ancient gospel reception. 


\section{MICHEL DE CERTEAU: ITINERARIES AND MAPS}

The French theorist Michel de Certeau (1925-1986) provides the framework for my discussion of Eusebius's gospel apparatus. In The Practice of Everyday Life (1984), de Certeau employs structuralist and post-structuralist literary theory to reconceive lived human spaces as texts. ${ }^{8}$ This homology, in turn, invites us to understand texts as human spaces, and thus to apply geographic insights to the reading of texts. ${ }^{9}$

In this study, I focus on de Certeau's distinction between two modes of describing physical space, which he terms "itineraries" and "maps." "10 As de Certeau frames these concepts, "description oscillates between the terms of an alternative: either seeing (the knowledge of an order of places) or going (spatializing actions). Either it presents a tableau ('there are ...'), or it organizes movements ('you enter, you go across, you turn . . ')."11 The first of these, "seeing," corresponds to the map. The second, "going," corresponds to the itinerary. The result is a divided discourse of space, which opposes itineraries to maps, going to seeing, space to place, proximity to distance. As de Certeau explains, "The question ultimately concerns the basis of everyday narrations, the relation between the itinerary (a discursive series of operations) and the map ( $a$ plane projection totalizing observations)."12

As a spatial sequence of lived experience, itineraries are like the imprints of human footsteps. They are an incomplete "record of fragments.", They rely on "two especially fundamental stylistic figures: synecdoche and asyndeton. [. . .] Synecdoche expands a spatial element in order to make it play the role of a 'more.' [ . . . Asyndeton, by elision, creates a 'less,' opens gaps in the spatial continuum, and retains only selected parts of it that amount almost to relics." 14 As traces of human life and human narrating, itineraries do not attempt to provide an 
all-encompassing, God's-eye perspective. By contrast, de Certeau contends that the map has dissociated itself from the itinerary in such a way that the map can "[collate] on the same plane heterogenous places." ${ }^{15}$ Unlike the itinerary, the map is a "totalizing" discourse that attempts to control and regularize space from an external, "scopic" position.

In this study, I rely on de Certeau's contrast between the itinerary and the map to articulate the distinctive contribution of Eusebius's paratextual apparatus. As we will see, Beck's map of the London Tube provides an apt metaphor.

\section{THE EUSEBIAN APPARATUS AND THE LONDON TUBE}

We turn now to consider the Eusebian apparatus itself. The gospel narratives that became canonical-Matthew, Mark, Luke, and John—are, in de Certeau's terms, textual itineraries. ${ }^{16}$ As they move from pericope to pericope, their structure is episodic. Consider for example the ubiquitous Markan “immediately” ( $\varepsilon \dot{\theta} \theta \dot{\varepsilon} \omega \varsigma)$. Recent redaction-critical approaches have emphasized the episodic appropriation and re-ordering of material in early gospel writing. ${ }^{17}$ Asyndeton or synecdoche often disguise the fact that the meandering path taken is not necessarily the simplest or most straightforward narrative route-or even that the events are impossibly out of order. ${ }^{18}$ Eusebius sought to facilitate a unified reading of these four divergent narratives.

To better understand the structure and operation of the Eusebian apparatus, let us now return to the analogy of the London Tube. One might imagine each of the four canonical gospels as a single rail line, moving from station to station. Some stops (some pericopes) are only served by a single line (a single gospel). But quite frequently, multiple lines (multiple gospels) pass through the same stops (the same pericopes). Even so, however, there is no guarantee that the 
lines visit these stops in the same order. While the lines intersect often, they frequently do not run in parallel. As a result, when the reader changes lines (gospels) there is no guarantee that the new line (gospel) will not take her back somewhere she has already been.

Instead of trying to compel these four gospel itineraries to run in parallel with each other, Eusebius's map identifies intersections between them. To do this, the apparatus consists of three components. First, Eusebius explains the system in his Epistula ad Carpianum. Second, numbers in the margins of the running gospel text mark individual sections. Finally, a set of ten reference tables ("canons"), typically placed near the beginning of the gospel manuscript, correlates these sections. ${ }^{19}$ The marginal annotations for each section consist of two numbers. ${ }^{20}$ The first identifies the sections in each gospel sequentially from the beginning of that gospel. The second number identifies which of the ten reference tables coordinates this section with parallel units from the other gospels. If we imagine the gospels in Eusebius's system as a series of Tube lines, then each set of corresponding numbers is a station.

The visual arrangement of the Eusebian apparatus is also valuable for the reader. Simply by looking at the canon number in the margin of a gospel text, one can know which lines (so to speak) pass through a given station — a significant benefit for the user of the map. The first of the ten tables correlates material found in all four gospels. The next three tables (canons II-IV) identify material found in three gospels. The next five tables (canons V-IX) identify material found in only two gospels. The final table (canon X) consists of four sections, each identifying material found in only one gospel (served by only one line). Eusebius's apparatus thus maps both convergence and divergence in the gospel itineraries.

To illustrate the organization of the Eusebian apparatus, we will consider the beatitudes of Matthew (Matt 5.2-11; Matt $\S 25-30)$. As Eusebius is well aware, the passage shares material 
with the beatitudes of Luke (Luke 6.20-22; Luke $\S \S 46-49$ ). But Eusebius does not simply mark the two sets of beatitudes as parallel, since the Matthean collection includes a number of sayings absent from the Lukan version, and even the shared sayings are not in the same order. Similar versions of the introductory formula and first beatitude ("the poor") appear in both gospels. Eusebius thus assigns both (Matt $\S 25 / /$ Luke $\S 46$ ) to canon V, which contains material found in both Matthew and Luke. The next beatitude in Matthew ("those who mourn"; Matt §27) is also shared with Luke, but the beatitudes in Luke occur in a different order. In Luke, the blessing on “those who hunger” (Luke $§ 47 / /$ Matt $§ 28)$ precedes the blessing on “those who mourn” (Luke $\S 48 / /$ Matt $§ 27)$. These also are assigned to canon $\mathrm{V}$, but each is numbered as a separate section so that the canon table will represent the differences in order. The reader of Matthew can discover these Lukan parallels by consulting the canon tables of the manuscript. Matthew also includes four other blessings (Matt $§ \S 26,29)$ not found in Luke. ${ }^{21}$ These Eusebius assigns to canon $X$, but only two sections are required, since three of the blessings (Matt $§ 29=$ Matt 5.7-9) appear together without intervening material from another gospel. In this example, two key features of Eusebius's approach become clear. First, Eusebius offers a remarkably fine-grained analysis of gospel parallels, paying attention to both content and sequence. Second, the sections are not based on pericopes but on blocks of material found in a certain combination of gospels. ${ }^{22}$ The Eusebian apparatus is primarily about junctions between the gospels, and only indirectly about narrative units.

Just as significant, moreover, is the material that Eusebius's map omits. In Beck's map of the London Tube, actual distances between individual stations are irrelevant and the stations are represented at even intervals. Tube lines are represented by horizontal, vertical, or forty-fivedegree lines - however they might actually run on the ground. Rather than tracing the twists and 
turns of the Tube lines, Beck's map focused on their intersections with one another. Similarly, Eusebius's system provides a "map" of the canonical Tube system that focuses on junctions between the four gospels.

\section{CANONICAL SPACE}

In the previous section, I explained the structure and function of Eusebius's paratextual apparatus by comparing it to a subway map. I now turn to the historical context of the apparatus in order to assess Eusebius's distinctive contribution. De Certeau's concept of the itinerary makes it possible to articulate how Eusebius's fourfold-gospel project functions differently from earlier attempts to create a unified gospel. ${ }^{23}$ First, Eusebius's apparatus provides a map of the canonical gospels that does not reduce them to a single itinerary. Second, Eusebius avoids what de Certeau terms totalizing geography—with one significant exception. Finally, Eusebius's apparatus functions as a "second, poetic geography" which is productive of new itineraries through the fourfold canonical gospel.

\section{Itinerary: Declined and Preserved}

We begin by considering two of Eusebius's predecessors, Tatian and Ammonius. At least from Eusebius's perspective, both were also involved in the project of reading the fourfold canonical gospel as an integrated whole. Eusebius's approach, however, differed radically.

First, working near the end of the second century C.E., Tatian composed a unified gospel, known to Eusebius and to modern scholarship as the Diatessaron. ${ }^{24}$ Recently some scholars have questioned whether in fact this title is original, implying as it does that Tatian intended his

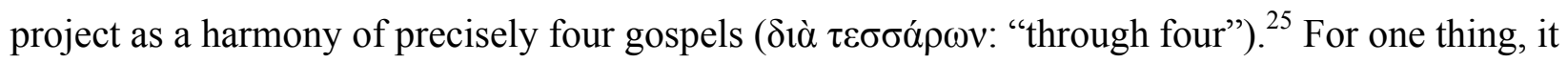


is unclear whether Tatian employed Mark at all, while he may have used material not found in any of the canonical four. ${ }^{26}$ Moreover, even in the fourth century C.E., the Syriac exegetes Aphrahat and (Ps-)Ephrem knew Tatian's work simply as "the gospel” (مגinoor rather than as a harmony of multiple sources. ${ }^{27}$ As a result, some have recently suggested that instead of being a harmony — that is, a continuous narrative composed of passages from different writings in order to exhibit or create agreement between them-Tatian's project was an act of "gospel writing" along the same redactional lines as Matthew or Luke. ${ }^{28}$ Clear answers to these questions are obscured by the fact that Tatian's original is no longer extant. ${ }^{29}$ But, regardless of Tatian's own intentions, Eusebius certainly regarded the text he called the Diatessaron as a gospel harmony. In the Ecclesiastical History, he asserts that "Tatian, their original leader [sc. of the Encratites] composed ( $\sigma v v \theta \varepsilon i ́ \varsigma)$ a certain combination and collection of the gospels-I do not

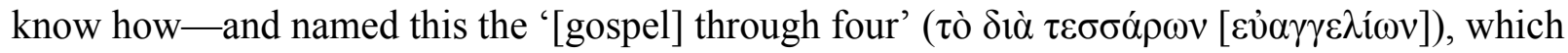
even still is used by some people." ${ }^{30}$ Moreover, the basic contours of Tatian's composition are clear. As Markus Bockmuehl explains, Tatian "typically selects one of the parallel accounts in a given pericope with the aim of weaving together a coherent narrative without significant additions of his own." 31 The result is a single narrative "itinerary" that both construes every gospel incident as part of the same linear trajectory and also limits or conflates divergent gospel perspectives on that incident. $^{32}$

Second, sometime in the early third century C.E., Ammonius of Alexandria created a gospel synopsis. ${ }^{33}$ Like a harmony, a synopsis collates passages from different writings (although in some cases the purpose might be to exhibit differences as well as agreements). Unlike the continuous narrative of a harmony, however, a synopsis implies a format (often by means of parallel columns) that enables the user to view multiple versions at once. 
Ammonius's project is known to us only from Eusebius's description in the Epistula ad Carpianum, but the basic format is not in dispute. ${ }^{34}$ As Eusebius summarizes, "Ammonius the Alexandrian, exerting great industry and zeal — as is fitting — has left us the gospel through four

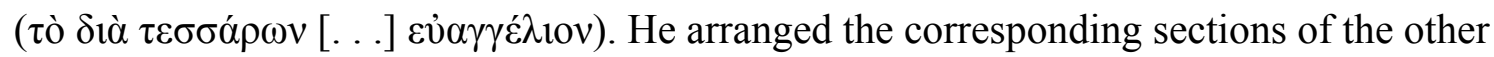

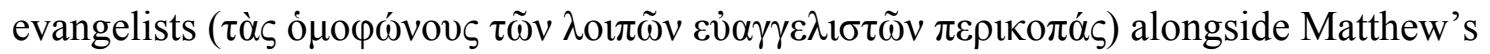
Gospel. ${ }^{\text {35 }}$ Unlike Tatian, Ammonius retains a multiplicity of perspectives by placing the four canonical accounts in parallel columns rather than harmonizing the details of each incident. ${ }^{36}$ In other words, he retains the synoptic function of a fourfold gospel. ${ }^{37}$ Nonetheless, Ammonius's project, arranged in parallel to Matthew, dissolves the narrative coherence of the other three gospels - except, of course, insofar as they correspond to Matthew. ${ }^{38}$ There may be different perspectives on the gospel events, but there is only Matthew's narrative.

Finally, working sometime in the first half of the fourth century (or perhaps even in the last decade of the third), ${ }^{39}$ Eusebius rejected Ammonius's synoptic method because it wrought havoc on the literary integrity of four independent gospels. ${ }^{40}$ Explaining the impetus for his own gospel apparatus, Eusebius criticizes this drawback of Ammonius's approach. As Eusebius tells us, Ammonius's decision to arrange the other evangelists alongside Matthew had "the unavoidable result that the coherent sequence of the other three was destroyed, preventing the reading of the context (v̋(o))." ${ }^{41}$ Like Ammonius, Eusebius preserves the integrity of individual gospel pericopes. But he also seeks to "preserve the scope and sequence of the remaining gospels throughout." Eusebius continues,

in order that $[. .$.$] you would still be able to know the proper passages ( \tau$ ov̀ $\varsigma$

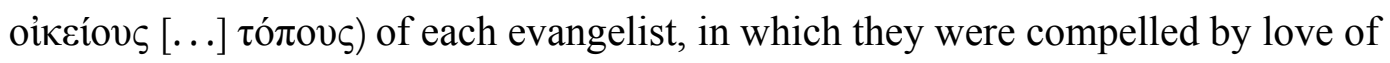
truth to say the same things, I have adopted the raw material ( $\dot{\alpha} \varphi \circ \rho \mu \alpha \dot{\varsigma})$ from the 
aforementioned man, but have inscribed by a different method the ten canons

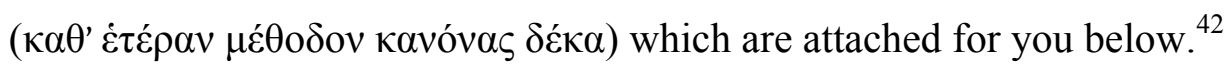

Eusebius is "materially indebted" to Ammonius for the parallels, although (as Matthew Crawford notes) "we cannot exclude the possibility that Eusebius tweaked the parallels here and there." Yet, while he gratefully incorporates the raw data of Ammonius's synopsis, Eusebius breaks from the synoptic model and refuses the parallel-column approach. ${ }^{44}$

Eusebius's apparatus allows the gospels to remain linear, fragmentary, asyndetic, synecdochic. That is, they exhibit the key characteristics of itinerary. ${ }^{45}$ Yet asyndeton and synecdoche within an individual gospel become visible only indirectly, insofar as the canon tables arrange the section numbers in new sequences. The reader of an individual gospel will always see the marginal section numbers increasing in order; the text itself remains in sequence. By recognizing that the textual geography of the four-gospel codex could be mapped in this way, Eusebius was able to devise an approach that preserved the integrity of the individual gospel narratives as itineraries. ${ }^{46}$ In contrast to the approaches of Tatian and Ammonius, the spaces are not forcibly filled in. With its manifold intersections between gospels, Eusebius's canonical map also defies the possibility of a single chronological itinerary. Indeed, Eusebius displays a remarkable unconcern about time, and does not attempt to place the gospel material into any overarching sequence. ${ }^{47}$ His map correlates four textual itineraries. As a result, Eusebius's method respects the narrative structures of all four gospels as literary compositions, different ways for the reader to walk through the life of Jesus.

In summary, Eusebius both declines and preserves itinerary. He rejects the harmonistic approach of Tatian, who reshaped gospel material into a single, comprehensive itinerary. But by declining itinerary as the governing principle of his canonical approach, Eusebius is able to 
preserve the four itineraries of the canonical gospels, and thus also rejects the synoptic approach of Ammonius. Instead, Eusebius locates the four narrative itineraries of Matthew, Mark, Luke,

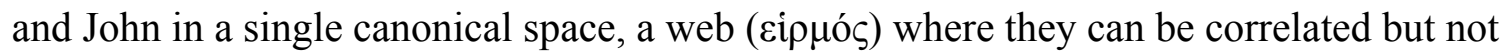
conflated. $^{48}$

\section{Totalizing Geography?}

To understand the implications of these observations, we should briefly recall how de Certeau distinguishes between itineraries and maps. The basic binary is between a sequential going and a scopic seeing that cannot be resolved into a single sequence. On these terms, Eusebius's apparatus is clearly a map, while the projects of Tatian and Ammonius are itineraries. But the previous section leads us to a surprising conclusion. On the one hand, the itineraries of Tatian and Ammonius exclude all other narratives. On the other, Eusebius's map of the fourfold gospel codex preserves existing gospel itineraries. This is precisely the opposite of what de Certeau's theory suggests.

As we noted briefly above, de Certeau asserts that maps offer a totalizing discourse which dissolves itineraries. The map encodes a "technological system of a coherent and totalizing space," for which itineraries must substitute "figures of pedestrian rhetoric." 49 As a map, then, the Eusebian apparatus is part of what de Certeau describes as 'the 'geometrical' or 'geographical' space of visual, panoptic, or theoretical constructions." ${ }^{\text {"50 }}$ De Certeau would thus suggest that Eusebius's map works on a fundamentally different order from the "migrational, or metaphorical" reality that is used "on the ground" (so to speak) in ordinary human experience. ${ }^{51}$ But by preserving multiple itineraries, Eusebius's cartographic creation problematizes de Certeau's theory. While offering a "technological system of a coherent" space, Eusebius's 
apparatus is not totalizing — with one key exception. ${ }^{52}$ Rather, mapping is an attempt at coherence that follows the "pedestrian rhetoric" of individual gospel itineraries.

There is a way, however, in which Eusebius's canonical gospel geography is totalizing. It is, after all, canonical and thus bounds the space within which one can posit connections between the gospels. Unlike Tatian, Eusebius consciously excludes intersections with noncanonical gospels. Returning to our Tube metaphor, Eusebius offers a map only for the ecclesial passenger lines — so where they meet (what he sees as) service corridors or other train systems is simply irrelevant. This is significant to Eusebius's canonical project and was not altogether to be assumed in his own day ${ }^{53}$ Perhaps just as significantly, Eusebius is similarly uninterested in parallels between the canonical gospels and Acts. ${ }^{54}$ More far-flung biblical parallels, such as citations or parallel narrative structures from the Old Testament, are also beyond the scope of his project.

Eusebius's project maintains the narrative integrity of the gospel itineraries, but also clearly delimits canonical space. De Certeau elsewhere describes the itinerary as the precondition of the map, from which the map has only slowly disengaged itself over the centuries. ${ }^{55}$ This may often be true. But in Eusebius's apparatus we discover a map that is intricately composed of itineraries.

\section{Navigating in Canonical Space}

While Eusebius's apparatus exhibits many features of a map, it also represents what de Certeau describes as a "second, poetic geography on top of the geography of the literal," a geographical mode of discourse that de Certeau ascribes to itineraries: "[t]hey insinuate other routes onto the functionalist and historical order of movement. Walking follows them." ${ }^{, 56}$ Within 
this "second, poetic geography," the "traces" of itineraries can "insinuate other routes." 57 In other words, the poetic geography created by the traces of itineraries suggests, even creates, new itineraries.

We observe this in the case of Eusebius's gospel apparatus. In de Certeau's terms, Eusebius's map makes possible a new set of practices, a new set of (textual) itineraries. By tracing the canonical gospel itineraries onto the same narrative plane, Eusebius's apparatus creates a canonical space and insinuates new routes through the canonical gospels for the reader to follow.

So, what can one do in this canonical space? In the following paragraphs, I briefly indicate three ways that the Eusebian apparatus insinuates new routes through the fourfold canonical gospel. Each of these three examples requires further research and discussion in its own right. Here they only illustrate the possibilities generated by the Eusebian apparatus.

First, liturgical sequences of gospel readings have often followed the Eusebian canons. ${ }^{58}$ Significantly, this is a point where time pushes back into the spatial structures of text and paratext. Sequences of gospel lections often follow textual itineraries which are insinuated by Eusebius's network of connections — but as a result of the liturgical year, these are again overlaid onto a performed chronological itinerary. Even then, annual variation in the liturgical calendar means that these itineraries continually trace slightly different paths through the canonical space which Eusebius mapped.

Second, Eusebius himself appears to have encoded a number of theologically productive exegeses into the apparatus. As Matthew Crawford emphasizes, "the decision of what is and is not a legitimate parallel at some point becomes an interpretive decision, and, indeed, Eusebius exploited precisely this fact to guide his readers towards a canonical reading of the fourfold 
gospel." ${ }^{59}$ Crawford assembles several examples of such "theologically suggestive crossreferences. ${ }^{, 60}$ For instance, Eusebius places the prologue to John (John 1.1-5, 9-10, $14=$ John $\S \S 1,3,5)$ in parallel to the genealogies of Matthew (Matt 1.1-16= Matt $\S 1)$ and Luke (Luke 3.23-38 = Luke $§ 14)$, although it is hardly self-evident that these all represent parallel material as such. Yet by placing these passages together in canon III, Eusebius suggests "something like a dual-nature Christology, in which the Matthean and Lukan accounts tell of the human origins of Jesus and the Johannine passages speak of his deity.",61

Finally, the Eusebian apparatus provided a technology for correlating and organizing knowledge in Late Antiquity (and beyond). Catena, a form of anthological commentary arranged around the biblical text, seems to have followed the routes indicated by the Eusebian apparatus. ${ }^{62}$ This is most obvious in the case of the Gospel of Mark. During Late Antiquity, it seems that relatively few exegetical works were written on Mark as such. ${ }^{63}$ As a result, William Lamb observes that "the compilers of the [Greek] Catena in Marcum [. . . ] used the Eusebian apparatus to search existing catenae and commentaries on Matthew and Luke so that they could find the relevant extracts for the equivalent passages in Mark. ${ }^{64}$ Thus, the Markan catena follows the narrative path of Mark through the texts and eyes of Matthew and Luke.",65

As these three examples demonstrate, Eusebius's apparatus generates a canonical space that not only preserves the narrative itineraries of the four canonical gospels, but also suggests trajectories for future journeying. While de Certeau does not envision this creative possibility as part of the geographical discourse represented by the map - after all, he distinguishes sharply between the lived space created by itineraries and the dead places charted by maps_-perhaps he would nonetheless have seen this as a reflection of the map's ultimate instability. Eusebius's (para)textual map continually reverts into practiced itineraries of reading and performance. 


\section{CONCLUSION}

In his Practice of Everyday Life, de Certeau emphasizes the unconscious nature of

everyday navigation, whether walking the street or making one's way through a written text. ${ }^{66}$ Because our navigation is often unconscious, maps and boundaries limit and direct our movement in ways that we may not notice. This observation is certainly pertinent to the role of paratextual features in the act of reading. This study has focused on the unnoticed power of a particular paratextual object, an apparatus on the physical borders of the canonical fourfold gospel. As the ancient biblical paratext par excellance, Eusebius's canonical map was part of the everyday experience of the biblical text and shaped the physical landscape of the gospels for much of Late Antiquity and the Middle Ages. ${ }^{67}$

In this study, I have argued that Michel de Certeau's distinction between itineraries and maps illuminates the distinctive features of Eusebius's gospel apparatus within the landscape of Late Ancient gospel scholarship. Faced with the problem of uniting multiple texts into a single ecclesial gospel, Eusebius rejected the approaches of harmony and synopsis. Instead, he created a map of the fourfold canonical gospel that articulated a single canonical space while nonetheless preserving the individual narrative itineraries of the four canonical gospels. While Eusebius's canonical space represents only the relationships between the canonical gospels, he refrains from a "totalizing" conflation or reduction of individual gospel itineraries. As a result, Eusebius's map enables its reader to trace new exegetical and liturgical itineraries through the canonical space which he charts.

Jeremiah Coogan is a PhD student in New Testament and Early Christianity at the University of 
Notre Dame. 
* I extend my sincere thanks to Markus Bockmuehl and Matthew Crawford for sharing unpublished material and offering insightful comments; to Martin Wallraff for kindly answering a number of queries; and to Blake Leyerle, Tzvi Novick, the members of the Proseminar in Early Christian Studies at the University of Notre Dame, and the two anonymous readers from JECS for their thoughtful and gracious feedback.

$1 \quad$ On Beck's map as a cartographic innovation, see e.g. Ken Garland, Mr Beck's Underground Map (Harrow Weld, Middlesex: Capital Transport Publishing, 1994); Clair Hutchings, "Influences in Geography: Harry Beck’s Map of the Underground," Geographical 67.2 (1995): 42.

2 On Eusebius's dates, see John Roberts, ed. The Oxford Dictionary of the Classical World (Oxford: Oxford University Press, 2005), 278. On Eusebius's biography and writings more broadly, see e.g. Timothy D. Barnes, Constantine and Eusebius (Cambridge, MA: Harvard University Press, 1981); Lorenzo Perrone, "Eusebius of Caesarea: Philology, History, and Apologetics for a Triumphant Christianity," in Early Christian Greek and Latin Literature. A Literary History, Vol. I: From Paul to the Age of Constantine, ed. Claudio Moreschini and Enrico Norelli (Peabody, MA: Hendrickson, 2005), 413-29; Anthony Grafton and Megan Hale Williams, Christianity and the Transformation of the Book: Origen, Eusebius, and the Library of Caesarea (Cambridge, MA: Harvard University Press, 2006). See also the recent collections of essays in Sabrina Inowlocki and Claudio Zamagni, eds. Reconsidering Eusebius: Collected Papers on Literary, Historical, and Theological Issues, VCSup 107 (Leiden: Brill, 2011); Jeremy Schott and Aaron Johnson, eds. Eusebius of Caesarea: Tradition and Innovations, Hellenic Studies 60 (Cambridge, MA: Harvard University Press, 2013). 
3 On the reception of the Eusebian apparatus in Armenian, Coptic, Ethiopic, Georgian, Gothic, Greek, Latin, Syriac, and other traditions, see H.H. Oliver, "The Epistle of Eusebius to Carpianus: Textual Tradition and Translation," NT 3.1-2 (1959): 138-45, at 140-43; Bruce M. Metzger and Bart D. Ehrman, The Text of the New Testament (New York, NY: Oxford University Press, 2005), 38; Michael Hollerich, "Eusebius," in The New Cambridge History of the Bible: From the Beginnings to 600, ed. James N. Carleton Paget and Joachim Schaper (Cambridge: Cambridge University Press, 2013), 629-52, at 637-38. Wallraff states that the Epistula ad Carpianum is the best-preserved non-biblical text from antiquity (Martin Wallraff, Kodex und Kanon: Das Buch im frühen Christentum, Hans-Lietzmann Vorlesungen 12 [Berlin: de Gruyter, 2013], 34-35). The apparatus itself was subject to further refinement in (at least) Latin, Armenian, and Syriac.

4 Since the early twentieth century, scholars have occasionally bemoaned this lack of attention to the Eusebian gospel apparatus: Eberhard Nestle, "Die Eusebianische Evangeliensynopse,” Neue kirchliche Zeitschrift 19 (1908): 40-51, 93-114, 219-32; Carl Nordenfalk, “The Eusebian Canon-Tables: Some Textual Problems,” JTS (n.s.) 35.1 (1984): 96104; Thomas O’Loughlin, "Harmonizing the Truth: Eusebius and the Problem of the Four Gospels," Traditio 65.1 (2010): 1-29; Wallraff, Kodex und Kanon, 34.

5 For art-historical discussion: Carl Nordenfalk, Die spätantiken Kanontafeln: Kunstgeschichtliche Studien über die eusebianische Evangelien-Konkordanz in den vier ersten Jahrhunderten ihrer Geschichte (Goteborg: Isacson, 1938); Carl Nordenfalk, "The Apostolic Canon Tables," Gazette des Beaux-Arts 105 (1963): 17-34; Dickran Kouymjian, “Armenian Manuscript Illumination in the Formative Period: Text Groups, Eusebian Apparatus, Evangelists' Portraits," in Il Caucaso: Cerniera fra culture dal Mediterraneo alla Persia (secoli IV-XI), 
Settimane di studio del Centro Italiano di studi sull'Alto Medioevo 43.2 (Spoleto: Presso la sede del Centro, 1996), 2:1015-49.

For other twentieth-century treatments: Nestle, "Eusebianische Evangeliensynopse;" Oliver, "Epistle of Eusebius to Carpianus;" Harvey McArthur, "The Eusebian Sections and Canons," CBQ 27.3 (1965): 250-56; Barnes, Constantine and Eusebius, 120-22; Carl Nordenfalk, “Canon Tables on Papyrus,” DOP 36 (1982): 29-38; Nordenfalk, "Eusebian CanonTables."

Catalogs and handbooks of New Testament manuscripts mention the Eusebian apparatus in passing, although not as an object of study in its own right. See briefly Bruce M. Metzger, Manuscripts of the Greek Bible: An Introduction to Palaeography (Oxford: Oxford University Press, 1981), 42 (§26); David C. Parker, An Introduction to the New Testament Manuscripts and Their Texts (Cambridge: Cambridge University Press, 2008), 315-16. Such text-critically focused discussions treat this apparatus as an aid for the user of the manuscript in a different way: "[i]t is still useful today if one is working with a manuscript and wishes to find a particular place in the text" (Parker, Introduction, 316, cf. 89-90). Several recent studies on the scribal habits of individual New Testament manuscripts provide more sophisticated discussion: Dirk Jongkind, Scribal Habits of Codex Sinaiticus, TSt 5 (Piscataway, N.J.: Gorgias, 2007), 109-20, cf. Appendix IV; W. Andrew Smith, A Study of the Gospels in Codex Alexandrinus: Codicology, Palaeography, and Scribal Hands, New Testament Tools, Studies, and Documents 48 (Leiden: Brill, 2014), 139-56.

6 The interest in paratexts draws its theoretical impetus from Gérard Genette, Paratexts: Thresholds of Interpretation, trans. Jane E. Lewin; Literature, Culture, Theory 20 (Cambridge; New York, NY: Cambridge University Press, 1997); French: Seuils (Paris: Editions du Seuil, 
1987). On paratexts in Eusebius's Roman milieu, see Jason König and Tim Whitmarsh, eds. Ordering Knowledge in the Roman Empire (Cambridge, England; New York, NY: Cambridge University Press, 2007); Laura Jansen, ed. The Roman Paratext: Frame, Texts, Readers (Cambridge: Cambridge University Press, 2014). In early Christian studies, see Martin Wallraff and Patrick Andrist, "Paratexts of the Bible: A New Research Project on Greek Textual Transmission," Early Christianity 6.2 (2015): 237-43.

7 For recent discussion (often quite brief), see James Joseph O’Donnell, Avatars of the Word: From Papyrus to Cyberspace (Cambridge, MA: Harvard University Press, 1998), 55-57; Grafton and Williams, Christianity, 194-200; O’Loughlin, “Harmonizing;” William R. S. Lamb, The Catena in Marcum: A Byzantine Anthology of Early Commentary on Mark, Texts and Editions for New Testament Study 6 (Leiden; Boston, MA: Brill, 2012), 146-49; Hollerich, “Eusebius,” 637-38; Jeremy Schott, “Textuality and Territorialization: Eusebius’ Exegeses of Isaiah, and Empire," in Eusebius of Caesarea: Tradition and Innovations, ed. A. Johnson and Jeremy Schott, Hellenic Studies 60 (Washington, D.C.: Center for Hellenic Studies, 2013), 16988, at 185-86; Martin Wallraff, "The Canon Tables of the Psalms: An Unknown Work of Eusebius of Caesarea," DOP 67 (2013): 1-14; Wallraff, Kodex und Kanon, 32-37; Matthew R. Crawford, "Ammonius of Alexandria, Eusebius of Caesarea and the Origins of Gospels Scholarship," NTS 61.1 (2015): 1-29; Francis Watson, The Fourfold Gospel: A Theological Reading of the New Testament Portraits of Jesus (Grand Rapids, MI: Baker Academic, 2016), 103-23; Markus Bockmuehl, Ancient Apocryphal Gospels, Interpretation: Resources for the Use of Scripture in the Church (Louisville, KY: Westminster John Knox, 2017), 12. Cf. Francis Watson and Judith S. McKenzie, eds. The Garima Gospels: Early Illuminated Gospel Books from Ethiopia (Exeter: University of Exeter Press, 2016), still forthcoming when this article was 
submitted for final publication. Martin Wallraff is now preparing a full edition as part of the ParaTexBib project at the University of Basel and Matthew Crawford is writing a monograph on the Eusebian canons and their reception, under contract with Oxford University Press. Interest has also appeared in the field of digital humanities: Joel Kalvesmaki, "Canonical References in Electronic Texts: Rationale and Best Practices,” Digital Humanities Quarterly 8.2 (2014): (electronic), discussing the origins of systems of canonical references (cf. the metaphors of "web" and "hyperlinks" in Wallraff, Kodex und Kanon, 34-37).

One should also note recent studies on the reception of the Eusebian apparatus in Hiberno-Latin scholarship, e.g. David Howlett, "Seven Studies in Seventh-Century Texts," Peritia 10 (1996): 1-70; Thomas O’Loughlin, “The Eusebian Apparatus in Some Vulgate Gospel Books,” Peritia 13 (1999): 1-92; Thomas O'Loughlin, “The Biblical Text of the Book of the Deer (C.U.L. II.6.32): Evidence for the Remains of a Division System from its Manuscript Ancestry," Scriptorium 63.1 (2009): 30-57; David Howlett, "Hiberno-Latin Poems on The Eusebian Canons," Peritia 21 (2010): 162-71; Elizabeth Mullins, “The Eusebian Canon Tables' HibernoLatin Exegesis: The Case Of Vienna, Österreichische Nationalbibliothek, Lat. 940," Sacris Erudiri 53 (2014): 323-43; Matthew R. Crawford, "Scholarly Practices: The Eusebian Canon Tables in the Hiberno-Latin Tradition," in Producing Christian Culture: Gospel Text and Gospel Commentary in Medieval Perspective, ed. Giles M. Gasper, Francis Watson, and Matthew R. Crawford Routledge, 2017), pages TBD (forthcoming).

8 Michel de Certeau, The Practice of Everyday Life, trans. Steven F. Rendall (Berkeley: University of California, 1984); French: L'invention du quotidien. 1/Arts de faire (Paris: Gallimard, 1980). For example, he describes New York City as "the most immoderate of human texts" (de Certeau, Practice, 92). 
9 On texts and stories, see de Certeau, Practice, 106-8, 115-30 et passim. For example, "Every story is a travel story—a spatial practice" (115).

10 de Certeau, Practice, 118-122.

11 de Certeau, Practice, 119. Emphasis and ellipses original.

12 de Certeau, Practice, 119. Emphasis added.

13 de Certeau, Practice, 107.

14 de Certeau, Practice, 101. The metaphors which de Certeau adopts for his discourse of space are originally terms from textual scholarship — which I now retrieve again to discuss textual geography.

15 de Certeau, Practice, 120-22, quote on 121.

16 Toward the end of this study, I discuss the absence of other possible parallel material; at present it is sufficient to note that Eusebius's project focuses exclusively on a fourfold gospel canon of Matthew, Mark, Luke, and John.

17 E.g. Francis Watson, Gospel Writing: A Canonical Perspective (Grand Rapids, MI:

Eerdmans, 2013); Francis Watson, “Towards a Redaction-Critical Reading of the Diatessaron Gospel,” Early Christianity 7.1 (2016): 95-112.

18 As Francis Watson observes, "[ $\mathrm{t}$ ]o the ordinary reader, whether ancient or modern, the narratives appear to weave in and out of one another without rhyme or reason" (Watson, Fourfold Gospel, 114).

19 The experienced user of the Nestle-Aland Handausgabe will be aware that it provides an editio minor and limited apparatus criticus for the Greek text of Eusebius's letter and the canon tables $(89 *-94 *$ in NA28). These, along with the marginal sigla, have been included in the modern-day paratextual apparatus of the Nestle-Aland Greek New Testament since its seventh 
edition. On the reasons for original inclusion, see Nestle, "Eusebianische Evangeliensynopse," which translates and discusses the Greek text of the letter. For English translations, see Oliver, “Epistle of Eusebius to Carpianus," 144-45; Barnes, Constantine and Eusebius, 121-22, as well as the partial translations of William L. Petersen, Tatian's Diatessaron: Its Creation, Dissemination, Significance, and History in Scholarship, VCSup 25 (Leiden: Brill, 1994), 33; Grafton and Williams, Christianity, 198; Crawford, “Ammonius," 6, 19; Watson, Fourfold Gospel, 117. The user of the United Bible Societies Handausgabe (in its various editions) will look in vain for the Eusebian apparatus. While recognizing their deficiencies, the present study employs the Greek text and marginal apparatus provided in the NA28. All translations are my own, although I have consulted the translations and secondary literature cited.

20 Smith, Study of the Gospels, 142-43, provides an excellent description of how these marginal features appear en page in the fifth-century C.E. Codex Alexandrinus; cf. the illustrations of Grafton and Williams, Christianity, 196-97. In Eusebius's original arrangement, the section numbers were written in regular (black) ink, while the canon numbers were written in red (see Epistula ad Carpianum, lines 25-30 [NA28, 89-90]). In the NA28, Arabic numerals represent the section numbers, while Roman numerals indicate the ten canons.

21 The careful reader will notice that in the NA28, Matt $§ 27$ precedes Matt $§ 26$. Eusebius’s method is clearer after a glance at the apparatus criticus reveals that a number of manuscripts reverse the beatitudes on "those who mourn" and "the humble" (Matt 5.4 and 5.5).

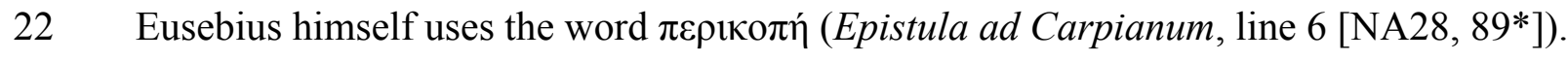
But as Crawford observes, "[t]hese sections do not correspond to sense units, in the manner of

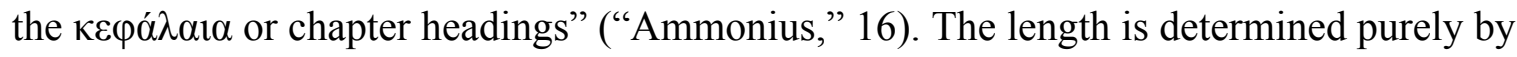
correspondence to the other gospels. For example, a single unit extends from John 8.21-10.13 (= 
John §89), since the entire section lacks synoptic parallels (or at least Eusebius does not adduce any). The NA28 introduction thus may be misleading when it states that "Eusebius divided the four Gospels into small units by content" (Eberhard Nestle et al., eds. Novum Testamentum Graece (Stuttgart: Deutsche Bibelgesellschaft, 2012), 85*). Confusion on this point obscures the basic function of the Eusebian apparatus as a correlational reference system.

23 See de Certeau, Practice, 106.

24 On Tatian's so-called Diatessaron, see Theodor Zahn, Tatians Diatessaron (Erlangen: Deichert, 1881); Peter M. Head, “Tatian's Christology and its Influence on the Composition of the Diatessaron," Tyndale Bulletin 43 (1992): 121-37; Petersen, Tatian's Diatessaron; Matthew R. Crawford, "Diatessaron, a Misnomer? The Evidence from Ephrem's Commentary," Early Christianity 4.3 (2013): 362-85; Ulrich B. Schmid, "The Diatessaron of Tatian," in The Text of the New Testament in Contemporary Research: Essays on the Status Quaestionis, ed. Bart D. Ehrman and Michael W. Holmes, New Testament Texts, Studies, and Documents 42 (Leiden: Brill, 2013), 115-42; Matthew R. Crawford, ““'Reordering the Confusion”: Tatian, the Second Sophistic, and the so-called Diatessaron," Zeitschrift für antikes Christentum / Journal of Ancient Christianity 19.2 (2015): 209-36; Matthew R. Crawford, "The Diatessaron, Canonical or Non-Canonical? Rereading the Dura Fragment," NTS 62.2 (2016): 253-77; Watson, "RedactionCritical Reading”; Bockmuehl, Ancient Apocryphal Gospels, 126-29. On Tatian himself, see Martin Elze, Tatian und seine Theologie, Forschungen zur Kirchen- und Dogmengeschichte 9 (Göttingen: Vandenhoeck \& Ruprecht, 1960); Frances Young, "Greek Apologists of the Second Century," in Apologetics in the Roman Empire: Pagans, Jews, and Christians, ed. Mark Edwards et al. (Oxford: Oxford University Press, 1999), 81-104; Emily J. Hunt, Christianity in the Second Century: The Case of Tatian, Routledge Early Church Monographs (London: Routledge, 
2003); Richard A. Norris, "The Apologists," in The Cambridge History of Early Christian Literature, ed. Frances Young, Lewis Ayres, and Andrew Louth (Cambridge, UK: Cambridge University Press, 2004), 36-44; Naomi Koltun-Fromm, "Re-Imagining Tatian: The Damaging Effects of Polemical Rhetoric," JECS 16 (2008): 1-30.

25 For this position, see Crawford, "Diatessaron, a Misnomer?"; Crawford, "Reordering the Confusion;" Watson, "Redaction-Critical Reading."

26 As Crawford has suggested, "Tatian used more than simply the canonical four, in keeping with his maximalist editorial approach" (see Crawford, “Diatessaron, a Misnomer?” 383; cf. Hunt, Christianity in the Second Century, 56). If (Ps-)Ephrem's Commentary on the Gospel reflects Tatian's work, then it may have included a passage from the Gospel of Peter ([Ps]Ephrem, Commentary on the Gospel 20.28) and a logion that also appears in the Gospel of Thomas 30 ([Ps-]Ephrem, Commentary on the Gospel 14.24). Francis Watson suggests a number of examples in which readings known to us from the Protevangelium Jacobi appear in the Tatian's work, although he is careful about claims of dependence and notes the possibility of shared oral tradition (Watson, "Redaction-Critical Reading," 106-8, 110-11). Discussion of this problem goes back at least to the nineteenth century; see Petersen, Tatian's Diatessaron, 99-100. 27 Crawford notes that Aphrahat and others thought the Syriac Gospel had been written by Jesus himself (Crawford, “Diatessaron, a Misnomer?” 372). For an extensive survey of references to Tatian's composition in Greek, Latin, and Syriac literature, see Petersen, Tatian's Diatessaron, 35-67.

28 Note especially Crawford, "Diatessaron, a Misnomer?”; Crawford, "Diatessaron, Canonical or Non-Canonical?"; Watson, "Redaction-Critical Reading," although the idea is already latent in Petersen, Tatian's Diatessaron, 74. Perhaps as an inevitable corollary to the 
indirect nature of our evidence for Tatian's composition, recent discussions about the nature of Tatian's sogenannte Diatessaron reveal a degree of slippage between Tatian's own understanding of his composition and its reception by (Ps-)Ephrem and other Syriac authorsalthough Crawford, "Diatessaron, Canonical or Non-Canonical?", obliquely addresses this issue by focusing on the Dura Fragment (see next note). While one should recognize this methodological imprecision, it may also be unavoidable given the current state of the evidence. 29 A small Greek fragment from Dura (Yale P.Dura 10) contains a composite passion narrative and has been identified as part of Tatian's opus. This identification has been challenged by David C. Parker, David G.K. Taylor, and Mark S. Goodacre, "The Dura-Europos Gospel Harmony," in Studies in the Early Text of the Gospels and Acts, ed. D.G.K. Taylor, Text Critical Studies 1 (Atlanta: SBL, 1999), 192-228 and defended by Jan Joosten, "The Dura Parchment and the Diatessaron," VC 57.2 (2003): 159-75; Crawford, "Diatessaron, Canonical or NonCanonical?"

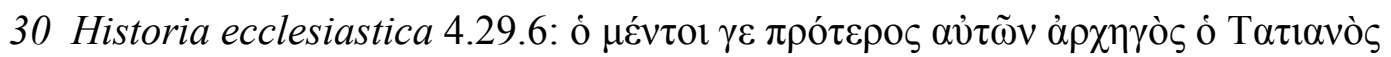

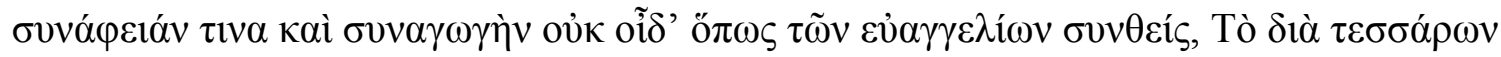

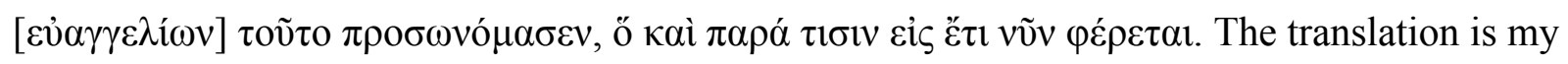
own, based on the text of Eduard Schwartz and Theodor Mommsen, eds. Eusebius Werke II/1, GCS (Leipzig: Teubner, 1903), 392, with the emendation in brackets suggested by Petersen, Tatian's Diatessaron, 35-37, based on the Syriac and Latin translations of Eusebius. This is in fact the earliest evidence for the title Diatessaron. Given Eusebius's use of the phrase

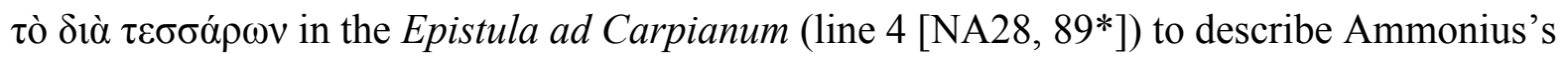
synopsis, it is particularly remarkable that he thus describes Tatian's work here in Historia ecclesiastica 4.29.6. 
31 Bockmuehl, Ancient Apocryphal Gospels, 126.

32 Crawford calls this "a radical repackaging of canonical material such that the original fourfold form is effectively erased and a new textual object emerges" (Crawford, "Diatessaron, a Misnomer?" 385). Likewise, "Tatian was not content to leave his source texts in the format that he found them, but radically altered their arrangement, creasing a new, single narrative" (Crawford, "Diatessaron, Canonical or Non-Canonical?" 254, cf. 261). Note possible parallels to Marcion, who also sought to create a unified gospel of a sort (cf. Crawford, "Diatessaron, a Misnomer?" 382-385; Crawford, “Diatessaron, Canonical or Non-Canonical?” 254n2; Bockmuehl, Ancient Apocryphal Gospels, 125-26, 230). On this as part of the ancient historian's role in reconciling narratives, see Petersen, Tatian's Diatessaron, 75-76 and cited sources. 33 On the identity of this Ammonius, see Elizabeth DePalma Digeser, A Threat to Public Piety: Christians, Platonists, and the Great Persecution (Ithaca, NY: Cornell University Press, 2012), 23-71; Crawford, "Ammonius," 3-6, and cited literature. According to Jerome (Epistula 121.6; De viris illustribus 25), Theophilus of Antioch (fl. ca. 169-183 C.E.) also compiled a gospel synopsis, although nothing of this project survives. On Theophilus's harmony, see brief discussion in Petersen, Tatian's Diatessaron, 32; Bockmuehl, Ancient Apocryphal Gospels, 12. 34 Debate persists about whether Ammonius's synopsis omitted the gospel material without Matthean parallel (as argued by Zahn, Tatians Diatessaron, 33) or left blank space in the Matthean column in order to accommodate interweaving this other material (as argued by Adolf von Harnack, Geschichte der altchristlichen Literatur bis Eusebius: Erster Theil (Leipzig: Hinrich, 1893), 406-7 and a revised position of Theodor Zahn, "Der Exeget Ammonius und andere Ammonii," ZKG 1 (1920): 1-22, at 7). Crawford, "Ammonius," 7-8, leaves the question open, while Watson, Fourfold Gospel, 117, suggests that Ammonius included the non-Matthean 
material as an appendix.

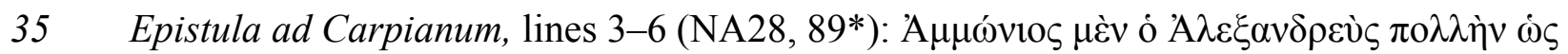

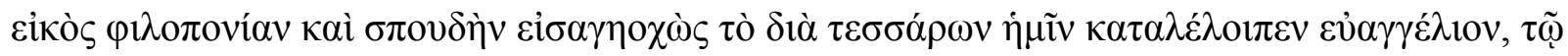

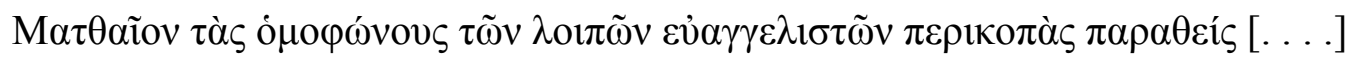

36 For thorough discussion of Ammonius's approach based on Eusebius's description in the Epistula ad Carpianum, see Crawford, "Ammonius,” 6-15; cf. Grafton and Williams, Christianity, 195. Crawford argues that "Ammonius dissected the latter three gospels in order to align the parallels he found there with the corresponding passages in Matthew" (Crawford, "Ammonius," 7). They were arranged in a four-column format similar to what we know of the six columns of Origen's Hexapla (“Origen's Hexapla provides us with the closest parallel for Ammonius’s Diatessaron-Gospel," Crawford, “Ammonius,” 6; cf. Grafton and Williams, Christianity, 178; Wallraff, Kodex und Kanon, 32). As observed by Crawford, "on the basis of this assumed continuity between the works of Ammonius and Eusebius, it should, in theory, be possible to reconstruct Ammonius's Diatessaron-Gospel by working backwards through Eusebius's modus operandi" (Crawford, “Ammonius,” 23).

37 Ammonius's synopsis may have been much like the modern version of Kurt Aland, ed. Synopsis quattuor Evangeliorum: Locis parallelis Evangeliorum apocryphorum et patrum adhibitis (Stuttgart: Deutschebibelgesellschaft, 1985), which instead (largely) follows the sequence of Luke.

38 Crawford's language of "Diatessaron-Gospel” reflects the Greek of the Epistula ad Carpianum, but it may unhelpfully imply that the description was a proper noun (see the argument of Crawford, “Ammonius," 8-12; cf. Oliver, "Epistle of Eusebius to Carpianus," 144). Crawford suggests that "Ammonius's title refers not to his four source texts [. . . but rather to 
the four-column manner in which he presented these texts" (Crawford, "Ammonius," 11)—-thus leaving open the possibility that Ammonius, like Tatian, occasionally included material not found in the canonical four.

39 Barnes, Constantine and Eusebius, 122, suggests the 290s C.E., based on the absence of the longer Markan ending from the original apparatus (a debatable point). Wallraff, "Canon Tables of the Psalms," 13, suggests the last decade of Eusebius's life (i.e., the 330s C.E.). 40 Pace Parker, Introduction, 316, who identifies the Eusebian apparatus as "a kind of simple synopsis.” Oliver likewise compares Eusebius's approach unfavorably to a modern synopsis, revealing that that he did not grasp the purpose of Eusebius's project (Oliver, "Epistle of Eusebius to Carpianus," 138).

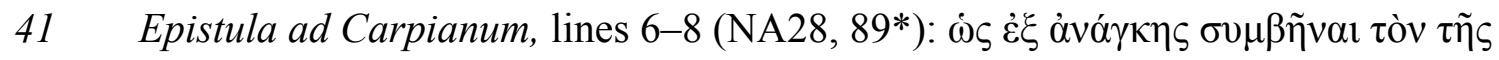

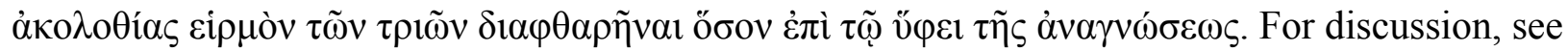
also Lamb, Catena in Marcum, 145-46.

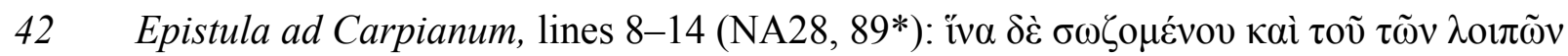

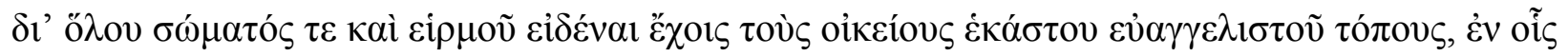

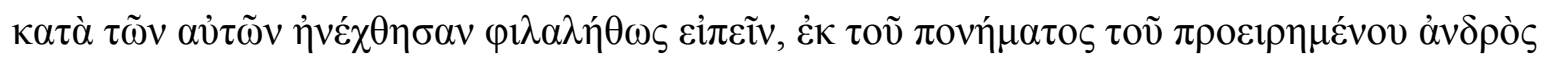

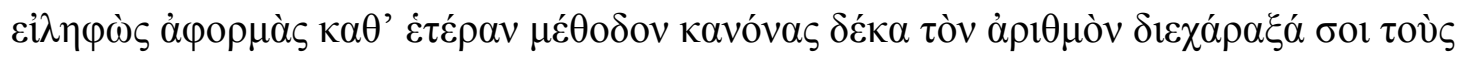

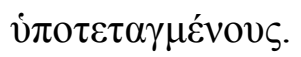

43 Crawford, "Ammonius," 2, 22. The mathematically-minded reader will have observed that Eusebius does not exhaust the possible configurations of parallels with his thirteen lists (the tenth canon is actually four lists). A full set of canons would include Mark-Luke-John and MarkJohn for a total of fifteen. While Crawford leaves open whether "Ammonius had also included non-Matthean parallels among the latter three gospels" ("Ammonius," 22), the absence of these 
possible tables is the strongest argument against the idea that Ammonius included non-Matthean gospel sections. While Crawford reconstructs the process which Eusebius would have followed in converting Ammonius's Matthew-based synopsis to paratextual canons, he does not fully explore the blind spots created by this procedure (“Ammonius," 22-23). Instead, he (along with McArthur, "Eusebian Sections and Canons," 251; Watson, Fourfold Gospel, 109) suggests that the omission of tables for Mark-Luke-John and Mark-John is "more likely simply due to the small amount of content for these canons" (Crawford, "Ammonius," 25). While this is true, Nordenfalk, "Canon Tables on Papyrus," 30, provides examples of passages for both canons. Following Nordenfalk (“Canon Tables on Papyrus,” 29), Crawford (“Ammonius,” 25), Lamb (Catena in Marcum, 146), and Smith (Study of the Gospels, 140 n.67) all offer a speculative arithmological explanation based on the significance of the number ten for Eusebius, rather than recognizing this as a result of Matthean primacy in the original Ammonian synopsis. (Watson, Fourfold Gospel, 109, offers a different theory of numerological symbolism.)

44 There is some debate on the relationship between Ammonius's sections and those of Eusebius (see Crawford, “Ammonius," 19-21 and cited literature). I follow Crawford's linguistic analysis of the (plural) $\dot{\alpha} \varphi \rho \rho \mu \alpha \grave{s}$ which Eusebius took from Ammonius as "raw data," and not simply "impetus." It is almost certain that Lamb is correct (Catena in Marcum, 146; cf. Barnes, Constantine and Eusebius, 122; Grafton and Williams, Christianity, 195, 198) and the reference numbers are the work of Eusebius: "Eusebius uses the raw data provided by Ammonius to assign consecutive reference numbers to each pericope in each of the four gospels." Contrast Smith, Study of the Gospels, 141, who seems to miss this distinction; this, in turn, leads him to suggest (153) that the Ammonian sections were present and numbered in the exemplar of Codex Alexandrinus, but that the corresponding Eusebian canons had to be supplied from a different 
manuscript. A much simpler explanation of the data (and the observation of 'cascading errors' in the numbering) is that the scribe made these errors because he or she copied the rubricated and black parts of the marginal annotation in separate rounds. The different colors of ink make this a reasonable explanation.

45 de Certeau, Practice, 93.

46 Although Eusebius is quite concerned in the Epistula ad Carpianum to put all four gospels on the same level, in practice, the canon tables may reflect canonical prioritization. That is, Matthew is placed prior to Mark, Mark to Luke, and Luke to John. (Note, however, that in canon VIII, Luke precedes Mark.) Canonical hierarchy is a feature of the canons only, since when reading any gospel, the section numbers always go up in proper sequence. Nonetheless, this unintentional side-effect of Eusebius's method remains noticeable in the canon tables themselves. (The author is grateful to Robert Edwards and an anonymous reviewer for their observations on this point.)

47 On Eusebius's disregard for chronology (all the more notable given his work as a chronographer), see for example the parallels between the cleansing of the Temple in John (John 2.14-16 = John §21) and the synoptics (Matt 21.12-13; Mark 11.15b-17; Luke 19.45-46= Matt $\S 211$; Mark §121; Luke §238).

48 For the language of eipuós, see Epistula ad Carpianum, line 7 (NA28, 89*).

49 de Certeau, Practice, 102.

50 de Certeau, Practice, 93.

51 de Certeau, Practice, 93. Emphasis original.

52 de Certeau, Practice, 102.

53 By the early fourth century, it seems that — with the exception of Tatian's gospel— 
narrative gospels corresponding to the Markan outline had largely failed to compete with the four gospels that became canonical. Nonetheless, a number of texts, especially so-called Jewish Christian gospels, circulated on the fringes of the fourfold canonical tradition (perhaps especially in the physical margins of Matthew). It is interesting that Eusebius does not map any such connections, since he participates in a tradition of biblical philology (from Clement and Origen through Eusebius to Jerome) that is willing to cite such gospel material as supplemental to the four. (On Eusebius and Origen, compare Perrone, "Eusebius of Caesarea," 413-14; Grafton and Williams, Christianity; Crawford, “Diatessaron, a Misnomer?” 381-82; on Jewish Christian gospels, see Bockmuehl, Ancient Apocryphal Gospels, 92-103).

One might contrast a modern synopsis like that of Aland. For example, under the heading of “Die Seligpreisungen” (Matt 5.3-12//Luke 6.20b-23), Aland also includes references to 1 Peter, the Epistle of Barnabas, Clement of Alexandria's Protrepticus, 1 Clement, Polycarp's Letter to the Philippians, the Didache, and the Gospel of Thomas (Aland, Synopsis, 75-76).

54 For example, parallels between Acts 1 and the ascension narratives of Matthew 28 and Luke 24. (Here again contrast the approach of Aland, Synopsis, 510-11.)

55 de Certeau, Practice, 120: "Over the past five centuries, the map has slowly disengaged itself from the itineraries that were the condition of its possibility."

56 de Certeau, Practice, 105.

57 de Certeau, Practice, 105.

58 This has recently been explored in Stefan Royé, "The Cohesion Between the AmmonianEusebian Apparatus and the Byzantine Liturgical Pericope System in Tetraevangelion Codices: Stages in the Creation, Establishment and Evolution of Byzantine Codex Forms," in A Catalogue of Byzantine Manuscripts in their Liturgical Context: Challenges and Perspectives., ed. Stefan 
Royé, Klaas Spronk, and Gerard Rouwhorst (Turnhout: Brepols, 2013), 55-116. Cf. Nordenfalk, “Canon Tables on Papyrus," 36-37.

59 Crawford, "Ammonius," 26. Cf. McArthur, "Eusebian Sections and Canons," 252-53.

60 Crawford, "Ammonius," 1, cf. 26-27. Crawford provides a number of further examples in a paper on "Eusebius of Caesarea's Gospel Canons as a Hermeneutical Key to the Fourfold Gospel" (presented at the Society of Biblical Literature 2015 Annual Meeting). I am grateful to him for sharing his unpublished work.

61 Crawford, “Ammonius," 27-28. Cf. Head, "Tatian’s Christology."

62 It is fascinating that this way of following Eusebius's (paratextual) map was also often transcribed paratextually. On catena, see Robert Devreesse, “Chaînes exégétiques grecques,” $D B$ 1 (1928): 1084-1233; Gilles Dorival, Les chaînes éxégetiques grecques sur les Psaumes:

Contribution à l'étude d'une forme littéraire, Spicilegium Sacrum Lovaniense 43-46 (Leuven: Peeters, 1986); R. B. ter Haar Romeny, A Syrian in Greek Dress: The Use of Greek, Hebrew, and Syriac Biblical Texts in Eusebius of Emesa's Commentary on Genesis, Traditio Exegetica Graeca 4 (Leuven: Peeters, 1997), 19-25; P.M. Parvis, “La chaîne sur la Genèse: Édition intégrale. 1: Chapitres 1 à 3,” JTS (n.s.) 48.1 (1997): 284-86; Lamb, Catena in Marcum; Ekkehard Mühlenberg, "Catena. II. Christianity,” Encyclopedia of the Bible and its Reception 4 (2012): 1061-64.

63 On the paucity of formal commentary on Mark in Late Antiquity, see e.g. Markus Bockmuehl, "The Making of Gospel Commentaries," in The Written Gospel, ed. Markus Bockmuehl and D.A. Hagner (Cambridge, UK: Cambridge University Press, 2005), 274-95, at 288-89. Cf. Lamb, Catena in Marcum, 147-49.

64 Lamb, Catena in Marcum, 147. 
65 Lamb, Catena in Marcum, 147-49. One result of this was to make interpreters particularly aware of when the Markan itinerary diverged from those of Matthew and Luke. As Jeremy Schott observes with reference to Eusebius's project more broadly, "By providing a cross-referencing system for parallel material in the gospels, the Canons encourages at least two modes of territorialization. First, it subdivides each gospel text into regions. Second, it asks its readers to colonize the text of Mark with the text of Matthew, to populate Luke with John, and so forth” (Schott, “Textuality and Territorialization," 186).

66 de Certeau, Practice, 126-29.

67 Martin Wallraff and Patrick Andrist note that biblical paratexts offer "important witnesses to how the Bible was actually lived - its contexts in worship, scholarship, liturgy, social history, material value, and more" (Wallraff and Andrist, "Paratexts of the Bible," 242). 